\title{
Moloney Leukemia Virus
}

National Cancer Institute

\section{Source}

National Cancer Institute. Moloney Leukemia Virus. NCI Thesaurus. Code C14241.

A positive sense, single-stranded RNA (sSRNA) retrovirus species belong ing to the

Gammaretrovirus genus. It is a causitive agent for lymphoid leukemia in mice and other mammals. 